\title{
PERANCANGAN SISTEM ROKET KENDALI BERPEMANDU INFRAMERAH MENGGUNAKAN METODE PENGOLAHAN CITRA YANG DISIMULASIKAN DALAM TEROWONGAN ANGIN
}

\author{
Muhammad Hanifudin Al Fadli"), Munawar Agus Riyadi, dan Budi Setiyono \\ Departemen Teknik Elektro Universitas Diponegoro, \\ Jln. Prof. Sudharto, SH Kampus UNDIP Tembalang, Semarang 50275, Indonesia \\ ${ }^{*}$ E-mail : hanifudinmuhammad@yahoo.co.id
}

\begin{abstract}
Abstrak
Roket kendali adalah sistem senjata berbasis roket yang memiliki pengendalian otomatis untuk mencari target dan menyesuaikan arah terbangnya. Pada Penelitian ini dirancang sebuah prototipe sistem roket kendali dengan sensor pelacakan sasaran inframerah menggunakan kamera webcam yang dimodifikasi dengan penggantian lensa bawaan dengan lensa tapis pelewat sempit $940 \mathrm{~nm}$. Kamera tersebut diakses menggunakan Raspberry Pi untuk selanjutnya dilakukan proses penapisan citra menggunakan metode pengambangan parameter HSV. Mikrokontroler atmega328 dipasang untuk mengendalikan pergerakan 4 buah servo canard menggunakan metode kendali PID. Dilakukan pula pengambilan parameter IMU 9-DOF dari sensor giroskop dan akselerometer MPU-6050 serta kompas HMC58831 untuk ditampilkan dalam antarmuka C\#. Parameter data pelacakan sasaran dan IMU dikirimkan ke komputer menggunakan modul telemetri APC220. Sistem roket kendali yang dirancang kemudian disimulasikan gerakannya dalam terowongan angin. Keluaran dari penelitian ini menghasilkan prototype sistem roket kendali dengan instrumen pelacakan inframerah yang mampu melacak sasaran inframerah $940 \mathrm{~nm}$ dengan kecepatan pelacakan sebesar 49,81 FPS. Parameter pengambangan HSV untuk sasaran inframerah $940 \mathrm{~nm}$ bernilai hue 0-153, saturation 0-32 dan value 179-255. Parameter PID yang digunakan dalam simulasi dengan kecepatan angin $9 \pm 4 \mathrm{~m} / \mathrm{s}$ bernilai $\mathrm{kp}=7$, $\mathrm{ki}=0$, dan $\mathrm{kd}=50$. Data dari telemetri dapat ditampilkan dalam odometri 2D menggunakan C\#.
\end{abstract}

Kata kunci : OpenCV, Inframerah, Pengolahan Citra, PID, Roket Kendali.

\begin{abstract}
Missile are rocket-based weapon systems that have automatic controls to find targets and adjust its flight direction. This Research is design a guided missile prototype system with seeker made from modified webcam camera by replacing default lenses with narrow-band pass filter lenses $940 \mathrm{~nm}$. This camera is accessed by Raspberry Pi than process the image with thresholding HSV parameters of the captured image. Control rocket using atmega328 that command 4 canard servos by PID control method. This system also taking 9-DOF IMU parameters using MPU-6050 as gyroscope and accelerometers and HMC-58831 as magnetometer and shown it in C\# GUI. All data parameter are delivered to computer wirelessly using telemetry module APC220. This prototype then simulated its movements in wind tunnel. The output of this project resulted an infrared tracking instrument capable of tracking infrared targets with a wavelength of $940 \mathrm{~nm}$ with 49.81 FPS tracking speed. The appropriate HSV filtering parameters for $940 \mathrm{~nm}$ infrared targets are hue $0-153$, saturation $0-32$ and value 179-255. The PID parameters $\mathrm{kp}=7, \mathrm{ki}=0$, and $\mathrm{kd}=50$ are suitable for wind speed around $9 \pm 4 \mathrm{~m} / \mathrm{s}$. Data from telemetry can be displayed in 2D odometry using C\#.
\end{abstract}

Keywords: Guided Missile, Image Processing, Infrared, OpenCV, PID.

\section{Pendahuluan}

Roket kendali mengalami perkembangan dari generasi pertama yang menggunakan pengendalian manual dan generasi kedua yang menggunakan pengendalian semiotomatis. Keduanya mempunyai banyak kelemahan dan kemungkinan mengenai sasaran yang rendah. Karena alasan ini maka dikembangkan sistem pengendalian generasi ketiga yang menggunakan pengendalian secara otomatis [1].

Pada pengendalian secara otomatis, sensor yang digunakan dapat berupa sensor inframerah yang diletakkan pada ujung hidung roket. Sensor yang biasa disebut sebagai seeker dapat berupa sensor tunggal untuk kemudian dimodulasi dengan pola gelap terang, empat sensor yang 
disusun dengan pola empat kuadran maupun sensor pencitraan menggunakan kamera inframerah yang diolah menggunakan proses pengolahan citra digital [2] [3].

Beberapa penelitian tentang seeker dan teknologi roket kendali yang telah dilakukan antara lain "Rancang Bangun Prototype Awal Seeker IR pada Sistem Rudal : Karakterisasi, Modelling, Prototyping Awal" [4] yang telah dilakukan oleh Universitas Ahmad Dahlan bekerjasama dengan LAPAN dan BATAN. Sistem seeker ini menggunakan detektor inframerah $\mathrm{PbS}$ yang dapat menangkap radiasi pada panjang gelombang 1,8-2,6 um. Sensor yang dirancang dapat mendeteksi sasaran inframerah dengan daya 100 watt sejauh 24 meter.

Pada penelitian tesis "Airborne Infrared Target Tracking with The Nintendo Wii Remote Sensor" [5], sensor pelacakan roket kendali dibuat dari remote nintendo wii yang dapat mendeteksi radiasi inframerah dari sebuah sumber panas. Wiimote digunakan sebagai pemandu pesawat glider agar jatuh pada sasaran inframerah.

Pengembangan penelitian tentang sistem roket kendali masih sangat banyak dan luas. Dalam penelitian ini dirancang sebuah sistem roket kendali otomatis berpemandu inframerah yang disimulasikan dalam terowongan angin.

\section{Metode}

Sistem roket kendali yang didesain menggunakan sensor pelacakan dari webcam yang sudah dimodifikasi dengan penambahan lensa tapis pelewat sempit $940 \mathrm{~nm}$. Sasaran dilacak menggunakan perangkat lunak opencv yang diinstal pada papan raspberry pi. Dilakukan pula pengambilan data IMU menggunakan sensor giroskop dan akselerometer MPU6050 dan kompas HMC5883 menggunakan mikrokontroler atmega328. Kesemua data diatas dikirimkan ke komputer melalui modul tetemetri APC220 untuk ditampilkan dalam GUI avionik yang dibuat menggunakan perangkat lunak C\#. Metode kendali PID digunakan untuk mengolah data koordinat sasaran. Keluaran pengendalian PID dimasukkan kedalam rumus kinematika 4 sirip canard berbentuk " $\mathrm{X}$ " yang digunakan untuk mengarahkan arah gerak terbang roket kendali ke sasaran inframerah.

\subsection{Perancangan Perangkat Keras}

Perangkat keras yang dirancang meliputi perancangan mekanika roket kendali, perancangan sistem eletronika dan perancangan terowongan angin. Pada perancangan perangkat keras menggunakan desain yang ditunjukkan pada Gambar 1.

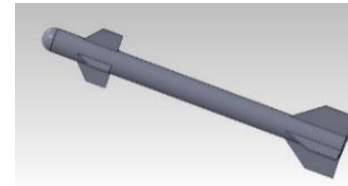

(a)

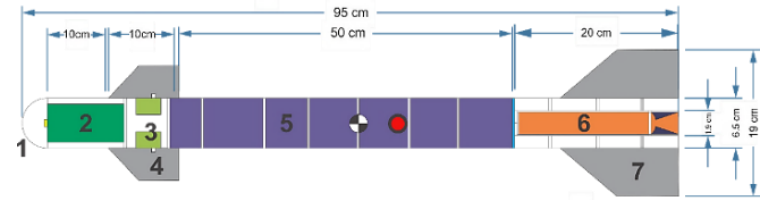

(c)

Gambar 1. (a) (b) (c) Rancangan mekanik dan penempatan muatan roket.

Bagian-bagian roket kendali beserta penjelasan masingmasing perangkat adalah sebagai berikut:

1. Radome : Berfungsi sebagai pelindung sensor pencitraan serta untuk menjaga keaerodinamisan aliran udara yang mengalir pada badan roket. Pada radome terpasang sensor kamera beserta lensa tapis inframerah.

2. Muatan : Tempat parasut sebagai sistem recovery setelah roket diluncurkan sehingga roket dapat mendarat dengan selamat.

3. Aktuator : Bagian aktuator roket kendali yang terdiri dari 4 motor servo dengan konfigurasi " $\mathrm{X}$ " relatif terhadap penempatan sensor inframerah.

4. Canard : Sirip pengendali roket bagian depan. Terbuat dari papan tripleks $3 \mathrm{~mm}$ dengan luas penampang masing-masing sirip $22,93 \mathrm{~cm}^{2}$.

5. Elektronika : Tempat menaruh sistem elektronika roket yang berupa Raspberry $\mathrm{Pi}$, mikrokontroler, sensor IMU, batere lipo, regulator, dan telemetri.

6. Tempat Motor Roket : Ruang kosong sebagai tempat untuk menempatkan motor roket.

7. Rudder : Sirip pada bagian ekor roket. Didesain tidak dapat bergerak. Luas penampang masingmasing sirip $48,39 \mathrm{~cm}^{2}$.

Perancangan sistem elektronika roket kendali ditunjukkan pada Gambar 2.

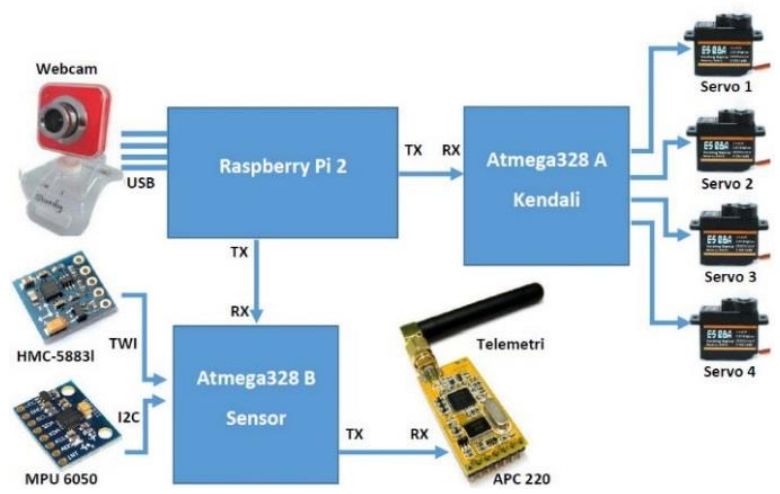

Gambar 2. Perancangan sistem elektronika roket kendali. 
Penjelasan fungsi komponen yang digunakan sebagai berikut :

1. Webcam Sturdy : Berfungsi sebagai sensor pencitraan inframerah

2. Raspberry Pi : Berfungsi sebagai pengolah citra digital.

3. Atmega328 A: Mikrokontroler untuk sistem kendali aktuator.

4. Atmega328 B : Mikrokontroler pembaca sensor IMU.

5. Motor Servo : Aktuator roket sebagai penggerak sirip canard.

Selain komponen diatas terdapat komponen tambahan sebagai piranti akuisisi data yang dikirimkan ke komputer. Data yang dikirimkan berupa data kemiringan roket sumbu $\mathrm{x}$, kemiringan roket sumbu $\mathrm{y}$, dan sudut heading kompas roket kendali. Piranti tersebut adalah :

1. MPU-6050 : Sensor giroskop dan akselerometer.

2. HMC58831 : Sensor kompas.

3. APC220 : Telemetri 433MHz untuk mengirimkan data ke komputer.

Untuk rangkaian penerimaan data di komputer menggunakan modul telemetri APC220 yang disambungkan dengan perangkat USB to TTL. Perangkat penerima data telemetri ditunjukkan pada Gambar 3.

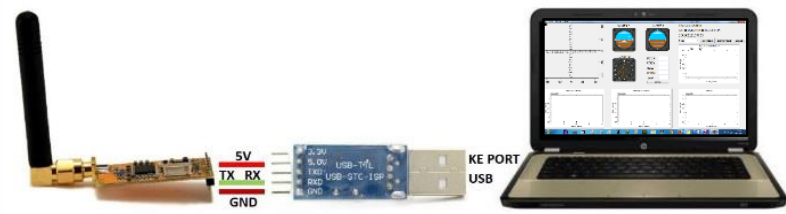

Gambar 3. Perangkat penerima data telemetri.

Catu daya roket kendali menggunakan batere Lipo 2S 650 $\mathrm{mAh}$. Untuk regulator yang digunakan menggunakan UBEC 15 A untuk regulator $5 \mathrm{~V}$ dan AMS1117 untuk regulator 3,3 V. Rancangan catu daya ditunjukkan pada Gambar 4.

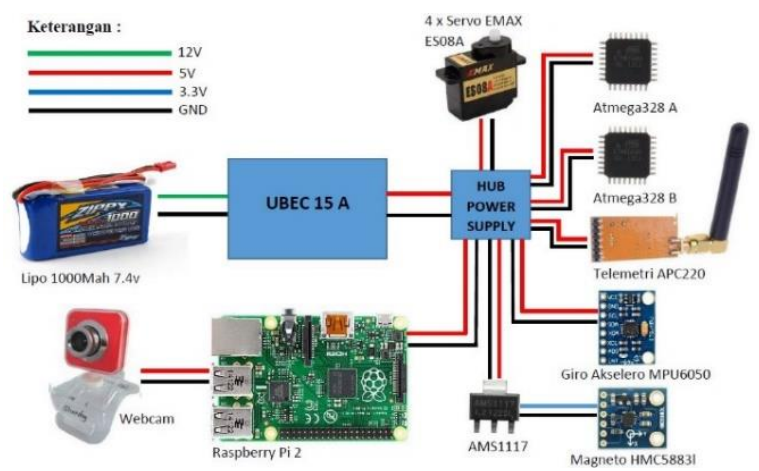

Gambar 4. Rangakaian catu daya roket kendali.

Sebelum diuji terbang, maka perlu dilakukan simulasi gerak roket dalam terowongan angin untuk menentukan nilai parameter-parameter kendali roket [6] [7]. Rancangan terowongan angin yang digunakan untuk melakukan simulasi gerakan roket kendali ditunjukkan pada Gambar 5.

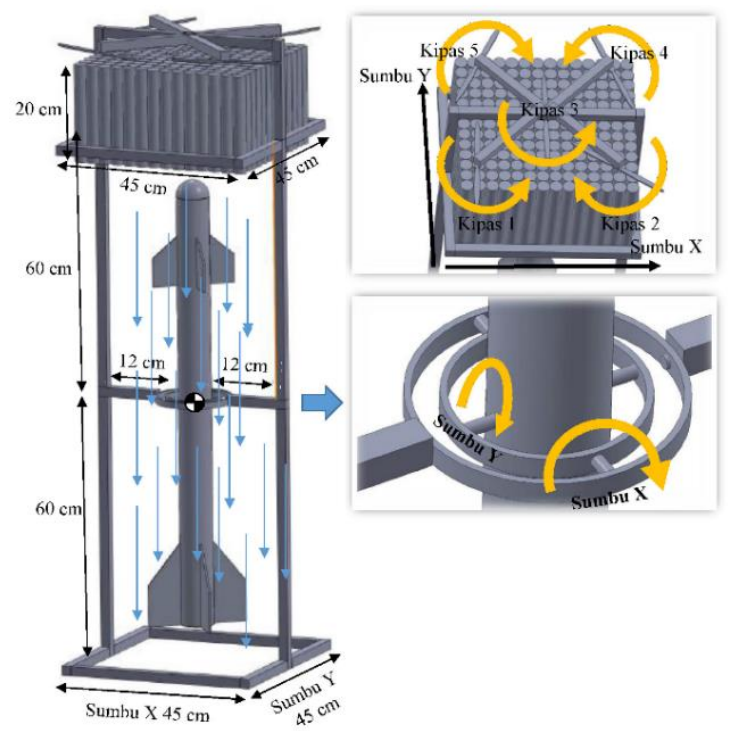

Gambar 5. Perancangan alat uji terowongan angin.

Spesifikasi alat pengujian terowongan angin ditunjukkan pada Tabel 1.

Tabel 1. Spesifikasi Terowongan Angin.

\begin{tabular}{lll}
\hline No. & Spesifikasi & Keterangan \\
\hline 1. & Panjang & $140 \mathrm{~cm}$ \\
2. & Lebar & $45 \mathrm{~cm}$ \\
3. & Tinggi & $45 \mathrm{~cm}$ \\
4. & Derajat kebebasan & 2 DOF \\
5. & Kecepatan angin & Max $15 \mathrm{~m} / \mathrm{s}$ \\
6. & CG roket & Di gimbal \\
7. & CP roket & $+2 \mathrm{~cm}$ dibawah gimbal \\
8. & Sasaran & LED inframerah $5 \mathrm{~mm}$ \\
9. & Maksimal kemiringan & $\pm 15^{\circ}$ \\
10. & Sumber angin & 5 brushless @1400 kv \\
11. & Catu daya motor & Lipo 4S $5400 \mathrm{mAh}$ \\
12. & Tuning angin & Manual \\
13. & Bahan rangka & PVC $3 / 4$ \\
14. & Diameter lubang angin & @10 mm \\
\hline
\end{tabular}

\subsection{Perancangan Perangkat Lunak}

Perangkat lunak yang digunakan dalam pemrograman raspberry pi menggunakan python. Pada library python diinstal modul opencv yang digunakan pada pengolahan citra digital. Citra yang didapat dari webcam kemudian dilakukan penapisan menggunakan metode pengambangan parameter HSV (hue, saturation dan value) citra. Tampilan antarmuka deteksi sasaran inframerah pada raspberry pi ditunjukkan pada Gambar 6.

Tidak seluruh citra yang didapatkan dari kamera diolah. Data citra yang diproses hanya pada daerah ROI (Region of Interest). ROI adalah daerah dimana dilakukan proses penapisan citra. Hal ini dilakukan untuk meminimalisir 
pendeteksian sasaran palsu yang mempunyai nilai HSV yang sama. Desain sistem update ROI dapat dilihat pada Gambar 7.

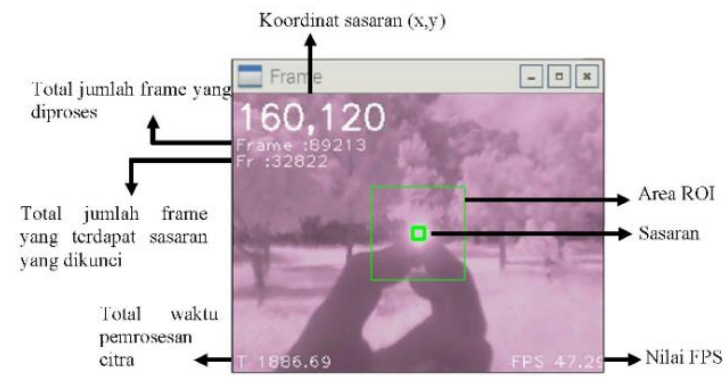

Gambar 6. Tampilan antarmuka deteksi sasaran.

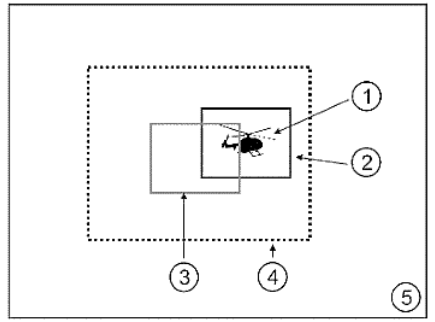

Gambar 7. Desain sistem update ROI (1 - Sasaran didalam ROI, 2 - Area ROI sekarang, 3 - Area ROI sebelumnya, 4 - Besar ROI maksimal, 5 - Frame yang diperoleh dari webcam).

Posisi ROI sekarang ditentukan oleh koordinat target sebelumnya. Titik tengah ROI sekarang diletakkan pada lokasi target sebelumnya. Apabila didalam ROI sebelumnya terdapat target namun didalam ROI sekarang target hilang, maka area ROI akan diperbesar 1,5 kali. Apabila masih belum ada juga target, area ROI akan terus diperbesar hingga mencapai besar ROI maksimal.

Koordinat citra yang telah tertapis kemudian dikirimkan ke mikrokontroler atmega328. Setelah dilakukan penyekalaan koordinat $\mathrm{x}$ dan $\mathrm{y}$ menjadi 100,100, dilakukan proses pengendalian PID koordinat sasaran citra dengan setpoint pada titik tengah citra yakni koordinat 50,50.

Keluaran pengendalian PID kemudian dimasukkan kedalam rumus kinematika pengendalian 4 servo canard roket kendali. Rumus pengendalian 4 servo canard menggunakan kofigurasi berbentuk " $\mathrm{X}$ " relatif terhadap penempatan sensor inframerah yang didesain ditunjukkan pada persamaan berikut.

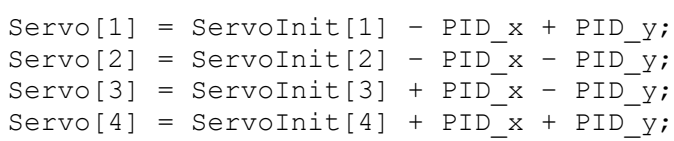

Konfigurasi sirip canard berbentuk " $\mathrm{X}$ " relatif terhadap penempatan sensor inframerah ditunjukkan pada Gambar 8.

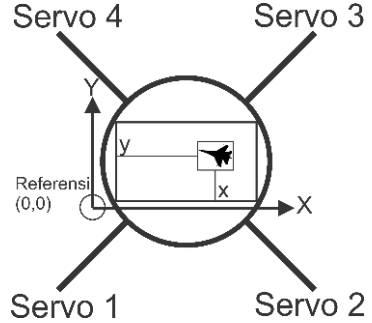

Gambar 8. Konfigurasi sirip canard berbentuk " $X$ ".

Data koordinat sasaran $\mathrm{x}$ dan $\mathrm{y}$ dari raspberry pi juga dikirimkan ke mikrokontroler atmega328 akuisisi data. Pada mikrokontroler atmega328 sistem akuisisi data dilakukan pula pembacaan sudut kemiringan roket kendali sumbu $\mathrm{x}$ dan y serta sudut heading kompas roket kendali.

Kelima data yang diperoleh mikrokontroler akuisisi data kemudian dikirimkan ke komputer menggunakan modul telemetri APC220. Data yang diterima ditampilkan dalam antarmuka avionik roket kendali yang didesain menggunakan perangkat lunak C\#. Tampilan antarmuka avionik roket kendali ditunjukkan pada Gambar 9.

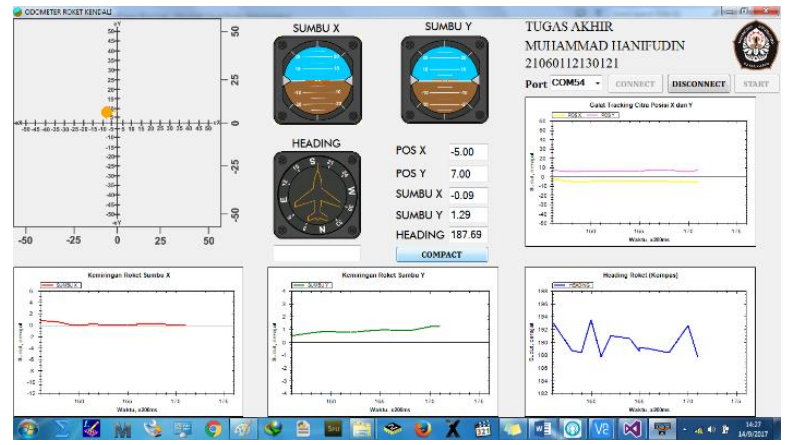

Gambar 9. Tampilan antarmuka avionik roket kendali

Tampilan avionik menampilkan data dalam bentuk grafik yang didesain menggunakan library zedgraph. Ditampilkan pula antarmuka avionik 2 dimensi tentang pergerakan koordinat sasaran $\mathrm{x}$, koordinat sasaran $\mathrm{y}$, kemiringan sumbu $\mathrm{x}$, kemiringan sumbu $\mathrm{y}$, dan sudut heading kompas roket kendali.

Selain ditampilkan pada antarmuka, kelima data parameter roket kendali juga disimpan dalam bentuk file yang bereksistensi .txt.

\section{Hasil dan Analisa \\ 3.1. Pengujian Catu Daya}

Pengujian catu daya dilakukan dengan mengukur tegangan dan arus pada sistem roket kendali. Pengukuran tegangan dilakukan pada keluaran regulator UBEC dan AMS1117. Hasil pengukuran tegangan disusun pada Tabel 2.

Tabel 2. Hasil pengukuran tegangan catu daya roket kendali. 


\begin{tabular}{cccc}
\hline $\begin{array}{c}\text { Pengukur } \\
\text { an ke }\end{array}$ & $\begin{array}{c}\text { Keluaran } \\
\text { Batere (V) }\end{array}$ & $\begin{array}{c}\text { Keluaran } \\
\text { UBEC (V) }\end{array}$ & $\begin{array}{c}\text { Keluaran } \\
\text { AMS1117 (V) }\end{array}$ \\
\hline 1 & 7,82 & 5,02 & 3,31 \\
2 & 7,73 & 5,03 & 3,31 \\
3 & 7,70 & 5,02 & 3,31 \\
4 & 7,68 & 5,02 & 3,31 \\
5 & 7,65 & 5,02 & 3,30 \\
Rata rata & 7,71 & 5,022 & 3,308 \\
\hline
\end{tabular}
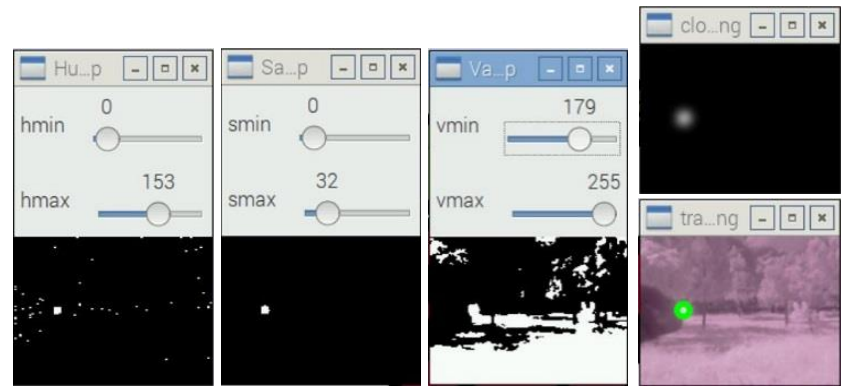

Pada pengukuran ke 1 dan seterusnya tegangan batere menurun yang diakibatkan pemakaian daya oleh sistem elektronik roket. Keluaran tegangan UBEC stabil dengan tegangan rata-rata 5,022 V dan keluaran AMS1117 sebesar $3,308 \mathrm{~V}$.

Pengukuran arus sistem elektronika roket kendali dilakukan pada bagian keluaran batere sebelum masuk ke regulator. Pengukuran dilakukan sebanyak 5 kali percobaan dengan kondisi sirip canard diam dan bergerak. Hasil pengukuran arus sistem elektronika disusun pada Tabel 3.

Tabel 3. Hasil pengukuran arus catu daya roket kendali.

$\left.\begin{array}{ccc}\hline \begin{array}{l}\text { Pengukur } \\ \text { an ke }\end{array} & \multicolumn{2}{c}{\text { Arus (Ampere) }} \\ \hline 1 & 0,57 & \text { Canard diam }\end{array}\right)$

Keluaran arus rata-rata pada saat sirip canard diam sebesar 0,608 A dan saat kondisi bergerak sebesar 1,12 A.

\subsection{Pengujian Parameter Penapisan Citra}

Parameter penapisan citra yang diuji adalah parameter nilai HSV (hue, saturation dan value). Pengambilan data pengambangan HSV dilakukan menggunakan sasaran LED inframerah $940 \mathrm{~nm}$ diameter $5 \mathrm{~mm}$ dari jarak $50 \mathrm{~cm}$. Pengujian dilakukan di lapangan GSG pada tengah hari dengan kondisi cerah.

Nilai pengambangan dikatakan pas apabila hasil pengambangan menunjukkan warna putih pada sasaran inframerah dan warna hitam di lingkungan sekitar. Hasil pengambangan nilai HSV yang tepat ditunjukkan pada Gambar 10 .

Gambar 10. Hasil pengambangan nilai HSV yang tepat.

Hasil pengambangan nilai hue dan saturation tidak menghasilkan banyak derau seperti yang terjadi pada nilai value. Meskipun demikian, derau yang muncul pada nilai value akan hilang karena ketiga komponen tapis akan dikalikan satu sama lain menggunakan operasi "AND”.

Data hasil pengambangan nilai HSV ditunjukkan pada Tabel 4

Tabel 4. Nilai pengambangan parameter HSV.

\begin{tabular}{llccc}
\hline No & Parameter & Nilai min & Nilai max & Rentang \\
\hline 1 & Hue & 0 & 153 & 153 \\
2 & Saturation & 0 & 32 & 32 \\
3 & Value & 179 & 255 & 77 \\
\hline
\end{tabular}

\subsection{Pengujian Respon Sensor Inframerah}

Pengujian respon sensor inframerah dilakukan untuk mengetahui jarak deteksi terhadap beragam sumber cahaya. Sumber cahaya yang digunakan berupa LED inframerah $940 \mathrm{~nm}$, lilin dengan diameter $1 \mathrm{~cm}$, lampu pijar 5 watt, lampu CFL 18 watt, lampu TL 18 watt dan lampu LED 18 watt. Pengujian dilakukan di lapangan GSG Undip pada tengah hari dengan kondisi cerah. Contoh pengujian terhadap lampu LED $940 \mathrm{~nm}$ ditunjukkan pada Gambar 11.

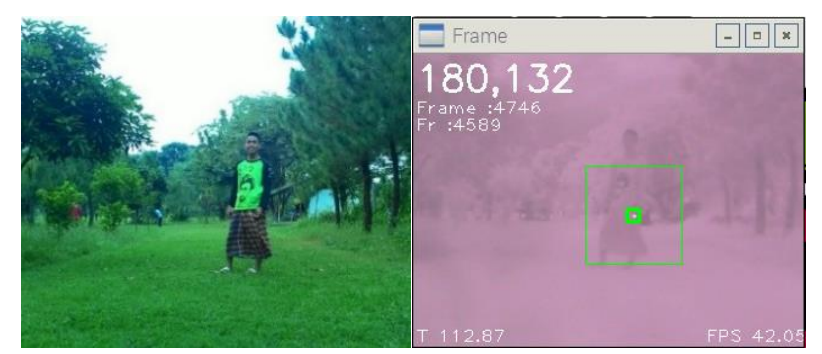

(a)

(b)

Gambar 11. (a) Citra lampu LED IR 940 nm diambil dari kamera biasa (jarak 7,2 m). (b) Citra lampu LED IR $940 \mathrm{~nm}$ diambil dari kamera inframerah (jarak 7,2 m). 
Sasaran yang terdeteksi ditandai dengan adanya bentuk persegi kecil berwarna hijau didalam area ROI. Apabila tidak ada persegi hijau kecil didalam area ROI berarti sasaran yang diuji tidak terdeteksi. Hasil pengujian respon sensor inframerah disusun pada Tabel 5.

Tabel 5. Respon sensor inframerah terhadap sumber cahaya

\begin{tabular}{llcc}
\hline No & Sumber cahaya & Hasil & Jarak maks \\
\hline 1. & LED IR 940 nm & Terdeteksi & $7,2 \mathrm{~m}$ \\
2. & Lilin & Terdeteksi & $16,1 \mathrm{~m}$ \\
3. & Lampu Pijar 5 W & Terdeteksi & $31 \mathrm{~m}$ \\
4. & Lampu CFL 18 W & Terdeteksi & $0,85 \mathrm{~m}$ \\
5. & Lampu TL 18 W & Tidak & - \\
6. & LED Putih 18 W & Tidak & - \\
\hline
\end{tabular}

Sasaran yang sama sekali tidak terdeteksi oleh kamera inframerah dapat disebabkan karena sasaran tidak memancarkan cahaya inframerah pada spektrum $940 \mathrm{~nm}$. Adapun salah satu faktor yang mempengaruhi jarak deteksi adalah jarak antara sasaran dan sensor inframerah terlalu jauh sehingga ukuran piksel sasaran inframerah terlalu kecil untuk dideteksi.

\subsection{Pengujian Ketegaran Sensor Inframerah Terhadap Cahaya RGB}

Pengujian ini dilakukan untuk mengetahui ketegaran sensor inframerah terhadap sumber cahaya yang memancarkan warna-warna dalam spektrum panjang gelombang yang berbeda. Seperti yang diketahui, warna merah mempunyai spektrum panjang gelombang 635-700 $\mathrm{nm}$, warna hijau pada panjang gelombang 490-560 $\mathrm{nm}$ dan warna biru pada panjang gelombang 450-490 nm [8]. Pengujian dilakukan di lapangan GSG Undip pada waktu siang hari cerah terhadap LED berwarna merah, hijau, dan biru dari jarak $50 \mathrm{~cm}$.

Contoh pengujian sensor inframerah terhadap sumber cahaya berwarna hijau ditunjukkan pada Gambar 12.

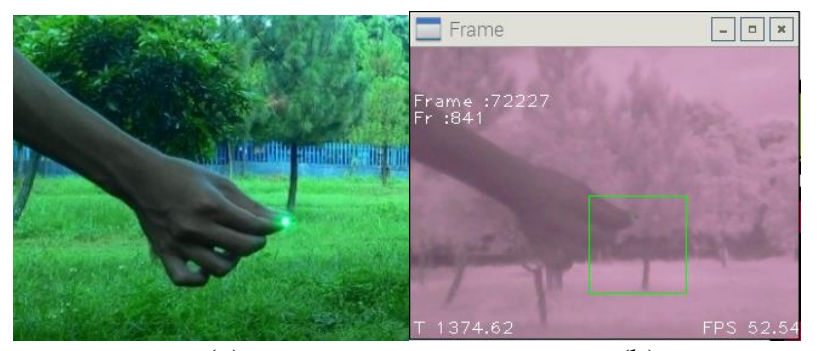

(a)

(b)

Gambar 12. (a) Citra lampu LED hijau diambil dari kamera biasa (jarak $50 \mathrm{~cm}$ ). (b) Citra lampu LED hijau diambil dari kamera inframerah (jarak $50 \mathrm{~cm}$ ).

Hasil pengujian ketegaran sensor inframerah terhadap sumber cahaya RGB ditunjukkan pada Tabel 6.
Tabel 6. Hasil pengujian sensor inframerah terhadap cahaya RGB.

\begin{tabular}{lcl}
\hline No & Pengujian LED 5 mm warna - & \multicolumn{1}{c}{ Hasil } \\
\hline 1. & IR $940 \mathrm{~nm}$ & Terdeteksi \\
2. & Merah & Tidak terdeteksi \\
3. & Hijau & Tidak terdeteksi \\
4. & Biru & Tidak terdeteksi \\
\hline
\end{tabular}

Hasil pengujian terhadap berbagai sumber cahaya yan memiliki warna RGB berbeda menunjukkan bahwa senso inframerah yang didesain memiliki ketegaran terhada sumber cahaya RGB.

\subsection{Pengujian Respon Sensor Inframeral Terhadap Penambahan Lensa}

Pengujian ini dilakukan untuk mengetahui apaka penambahan lensa dapat mempengaruhi pendeteksia sasaran inframerah. Sasaran yang digunakan dalar pengujian ini berupa lampu LED $940 \mathrm{~nm}$ berdiameter mm. Pengujian dilakukan di lapangan GSG Undip pad siang hari cerah. Lensa yang ditambahkan adalah lensa tel dan lensa fish eye. Contoh pengujian sensor inframera terhadap penambahan lensa tele ditunjukkan pada Gambar 13.

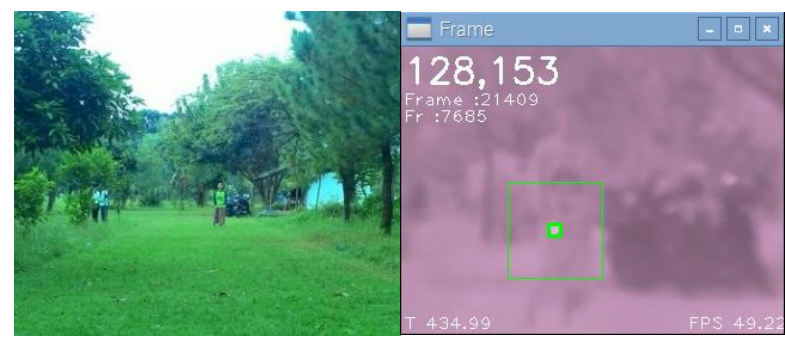

(a)

(b)

Gambar 13. (a) Citra lampu LED IR 5 mm 940 nm diambil dari kamera biasa (jarak $27,5 \mathrm{~m}$ ). (b) Citra lampu LED IR $5 \mathrm{~mm} 940 \mathrm{~nm}$ diambil dari kamera inframerah + lensa tele (jarak 27,5 m).

Hasil pengujian respon sensor inframerah terhadap penambahan lensa ditunjukkan pada Tabel 7.

Tabel 7. Respon sensor inframerah terhadap penambaha lensa.

\begin{tabular}{llcc}
\hline No & Lensa & Jarak deteksi maks $(\mathrm{m})$ & Sudut pandang $\left(^{\circ}\right)$ \\
\hline 1. & Normal & 7,2 & 90 \\
2. & Tele & 27,5 & 10 \\
3. & Fisheye & 6,4 & 120 \\
\hline
\end{tabular}

Dari hasil pengujian disimpulkan bahwa penambaha lensa dapat mempengaruhi pendeteksian sasara inframerah. Jarak pendeteksian sasaran bertambah jau apabila sensor inframerah ditambah dengan lensa tel namun sudut pandang menjadi lebih kecil. Apabila lens fish eye ditambahkan maka yang bertambah adalah sudu 
pandang, namun berkurang pada jarak pendeteksian sasaran.

\subsection{Pengujian Respon Sensor Inframerah Terhadap Pengaruh Sinar Matahari}

Pengujian ini dilakukan untuk mengetahui apakah dengan adanya sinar matahari atau tidak mempengaruhi pendeteksian sasaran inframerah. Pengujian dilakukan pada dua kondisi, yakni pada siang hari cerah dan pada malam hari. Pengujian dilakukan di lapangan GSG dengan sasaran LED inframerah $940 \mathrm{~nm}$ berdiameter $5 \mathrm{~mm}$. Hasil pengujian respon sensor inframerah terhadap cahaya matahari ditunjukkan pada Gambar 14.

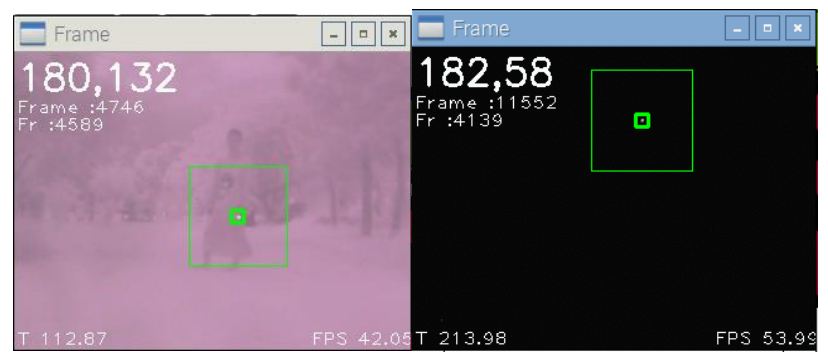

(a)

(b)

Gambar 14. (a) Citra lampu LED IR 940 nm diambil dari kamera inframerah pada siang hari (jarak 7,2 m). (b) Citra lampu LED IR $940 \mathrm{~nm}$ diambil dari kamera inframerah pada malam hari (jarak 45 m).

Hasil pengujian respon sensor inframerah terhadap pengaruh sinar matahari ditunjukkan pada Tabel 8 .

Tabel 8. Hasil pengujian sensor inframerah terhadap pengaruh cahaya matahari.

\begin{tabular}{lcc}
\hline No & Kondisi pengujian & Jarak deteksi maks (meter) \\
\hline 1. & Siang cerah & 7,2 \\
2. & Malam hari & 45 \\
\hline
\end{tabular}

Dari pengujian didapatkan hasil bahwa sinar matahari mempengaruhi jarak deteksi sasaran inframerah. Dengan sasaran yang sama, pendeteksian pada malam hari menghasilkan jarak jangkauan yang lebih jauh dibanding dengan jarak deteksi sasaran pada siang hari.

\subsection{Pengujian Kecepatan Pemrosesan Citra}

Kecepatan pemrosesan citra diperoleh dengan membagi jumlah frame citra yang tertapis dibagi total waktu penapisan. Satuan kecepatan pemrosesan citra adalah frame per second (FPS). Data kecepatan pemrosesan citra yang diambil selama satu menit ditampilkan pada Gambar 15.

Rata-rata kecepatan pemrosesan citra setiap detik adalah 49,81 FPS. Jika dilihat dari spesifikasi sensor yang dipakai yakni maksimal kecepatan pengambilan citra oleh webcam adalah 30 FPS. Dari hal ini dapat diketahui bahwa terdapat pemrosesan ganda, yaitu satu buah citra dapat tertapis lebih dari satu kali dalam satu siklus eksekusi program.

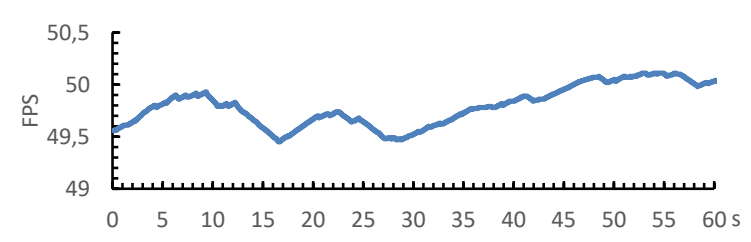

Gambar 15. Grafik nilai kecepatan pemrosesan citra yang diperoleh selama satu menit.

\subsection{Pengujian Kontroller PID}

Pengujian kontroller PID dilakukan untuk mencari parameter kontroller PID untuk mendapatkan respon sistem roket kendali yang stabil dalam mengikuti sasaran inframerah. Pengujian dilakukan dengan menempatkan sasaran inframerah tepat diatas roket. Roket kemudian dimiringkan hingga sudut $10^{\circ}$ arah sumbu x. ROI pelacakan sasaran kemudian digeser kearah sasaran.

Setelah kipas dinyalakan dengan kecepatan angin sebesar $9 \mathrm{~m} / \mathrm{s}$, roket dilepas sehingga kontrol PID bekerja mengendalikan galat sasaran sumbu $\mathrm{x}$. Pemilihan parameter PID dilakukan secara trial and error. Karakteristik sistem kontrol yang dibutuhkan adalah memiliki nilai rising time yang singkat, overshoot yang kecil dan nilai osilasi sebesar kurang dari $20 \%$ galat maksimal yakni dengan nilai \pm 10 .

Keseluruhan pengujian kontrol PID dilakukan dengan 6 variasi parameter kontrol. Rangkuman hasil pengujian kontrol PID ditunjukkan pada Tabel 9.

Tabel 9. Pengujian variasi PID dengan kecepatan angin 9 m/s.

\begin{tabular}{|c|c|c|c|c|c|}
\hline Kp & Ki & $\mathrm{Kd}$ & $\begin{array}{l}\text { Galat } \\
\text { awal }\end{array}$ & $\bar{\varepsilon}$ & Respon \\
\hline 3 & 0 & 0 & 42 & - & $\begin{array}{l}\text { Tidak mampu mencapai } \\
\text { setpoint. }\end{array}$ \\
\hline 5 & 0 & 0 & -16 & 5,04 & Berosilasi. \\
\hline 7 & 0 & 0 & -37 & 6,05 & Berosilasi. \\
\hline 9 & 0 & 0 & 40 & 15,76 & Berosilasi. \\
\hline 7 & 0 & 30 & 39 & 7,51 & Stabil, ts $=13,84 \mathrm{~s}$. \\
\hline 7 & 0 & 40 & 39 & 7,97 & Stabil, ts $=10,68 \mathrm{~s}$ \\
\hline 7 & 0 & 50 & 48 & 7,98 & $\begin{array}{l}\text { Stabil, ts }=6,82, \text { steady stat } \\
-6,59\end{array}$ \\
\hline 7 & 1.5 & 50 & 40 & 23,13 & Berosilasi. \\
\hline 7 & 1 & 50 & 43 & 20,34 & Berosilasi. \\
\hline 7 & 0,5 & 50 & 45 & 10,04 & Berosilasi. \\
\hline
\end{tabular}

Parameter PID yang dipilih untuk pengendalian rokt dengan kecepatan angin $9 \mathrm{~m} / \mathrm{s}$ adalah $\mathrm{kp}$ bernilai $7, \mathrm{k}$ bernilai 0 dan $\mathrm{kd}$ bernilai 50. Parameter tersebı diujicobakan dengan variasi kecepatan angin sebesar $5 \mathrm{~m} /$ dan $13 \mathrm{~m} / \mathrm{s}$. Hasil pengujian PID dengan variasi kecepatan angin disusun pada Tabel 10 . 
Tabel 10. Hasil pengujian PID dengan variasi kecepatan angin.

\begin{tabular}{|c|c|c|c|}
\hline No & $\begin{array}{l}\text { Galat } \\
\text { awal }\end{array}$ & $\begin{array}{l}\text { Kecepatan } \\
\text { angin }(\mathrm{m} / \mathrm{s})\end{array}$ & $\begin{array}{l}\text { Respon citra pelacakan roket } \\
\text { kendali sumbu } x\end{array}$ \\
\hline 1. & 36 & 5 & $\begin{array}{l}\text { Berosilasi dengan rata-rata } \\
\text { simpangan } 7,86 \text {. }\end{array}$ \\
\hline 2. & -48 & 9 & $\begin{array}{l}\text { Stabil, steady state pada }-6,59 \text {, rata- } \\
\text { rata simpangan } 7,98 \text {. }\end{array}$ \\
\hline 3. & 48 & 13 & $\begin{array}{l}\text { Berosilasi, dengan rata-rata } \\
\text { simpangan } 8,23 \text {. }\end{array}$ \\
\hline
\end{tabular}

Pada percobaaan variasi kecepatan angin $9 \pm 4 \mathrm{~m} / \mathrm{s}$ dengan kp 7, ki 0, dan kd 50 sistem kendali dinilai masih mampu mengarahkan arah gerak terbang roket kearah sasaran.

\subsection{Simulasi Sistem Roket Kendali}

Simulasi secara keseluruhan dilakukan dengan membaca seluruh data yang diterima oleh komputer melalui antarmuka C\#. Data yang dibaca merupakan data pengujian dengan nilai kp sebesar 7 , ki sebesar 0 dan $\mathrm{kd}$ sebesar 50 pada percobaan dengan kecepatan angin sebesar $9 \mathrm{~m} / \mathrm{s}$. Data pengujian ditampilkan pada Gambar 16 a -16 c.

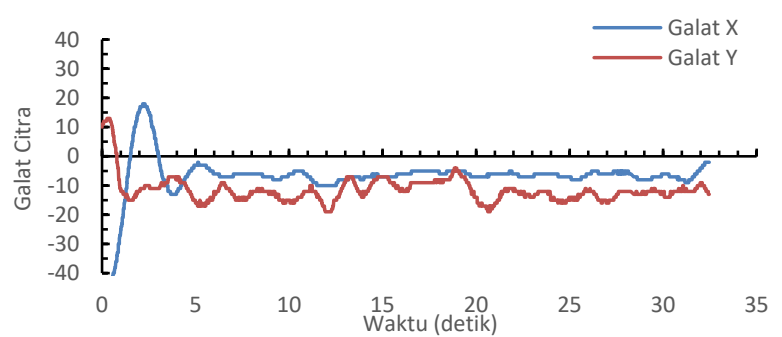

(a)

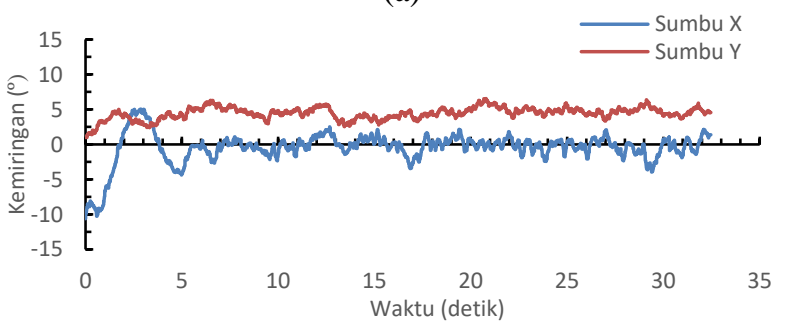

(b)

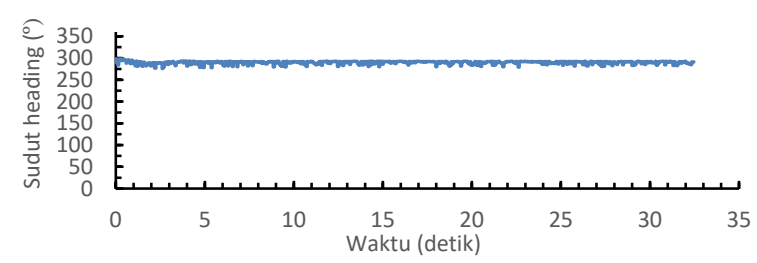

(c)

Gambar 16. Hasil pengujian simulasi roket kendali dengan kp 7, ki 0, kd 50 dan kecepatan angin $9 \mathrm{~m} / \mathrm{s}$. (a) Kemiringan roket. (b) Galat citra sasaran. (c) Sudut heading kompas roket.

Simulasi keseluruhan sistem roket kendali berhasil dilakukan pada terowongan angin dan data parameter roket kendali berhasil dikirimkan ke komputer dan ditampilkan ke antarmuka roket kendali.

\section{Kesimpulan}

Sistem roket kendali berhasil dirancang dan disimulasikan dalam terowongan angin. Sistem roket kendali yang didesain dapat melacak sasaran inframerah dengan panjang gelombang $940 \mathrm{~nm}$ dengan baik. Parameter pengambangan nilai HSV untuk sasaran inframerah $940 \mathrm{~nm}$ bernilai hue 0153, saturation 0-32 dan value 179-255. Rumus kinematika pergerakan 4 servo canard berbentuk " $X$ " relatif terhadap penempatan sensor berhasil digunakan untuk mengarahkan arah gerak terbang roket kendali kearah sasaran. Parameter PID yang tepat untuk pengendalian sistem roket kendali pada kecepan angin $9 \pm 4$ $\mathrm{m} / \mathrm{s}$ bernilai kp sebesar 7, ki sebesar 0 , dan kd sebesar 50 . Antarmuka yang didesain menggunakan $\mathrm{C \#}$ berhasil yang ditandai dengan dapat diterima keseluruhan data parameter pengujian.

Saran yang diberikan adalah dapat dikembangkan metode pemanduan menggunakan metode proportional navigation. Dapat ditambahkan pula gimbal dan teleskop cassegrain pada sensor pelacakan. Agar dapat melacak sasaran seperti pesawat atau tank, sensor kamera dapat diganti dengan kamera inframerah yang mempunyai respon terhadap panjang gelombang yang lebih tinggi. Dapat dikembangkan pula metode pelacakan TLD supaya pelacakan dapat lebih tegar. Untuk eksekusi data yang lebih cepat dapat menggunakan papan FPGA.

\section{Referensi}

[1]. A. E. Ozcan, "Autopilot and Guidance for Anti-Tank Imaging Guided Missiles," Middle East Technical University, 2008

[2]. C. Kopp, "The Sidewinder Story," Australia Aviation, 1994.

[3]. C. Kopp, "Fourth Generation AAMs," Australia Aviation on The Rafael Python 4, 1997.

[4]. D. H. S. Gunawan S. Prabowo, "Rancang Bangun Prototype Awal Seeker IR Pada Sistem Rudal: Karakterisasi, Modelling, Prototyping Awal," in Insinas, 2012,

[5]. A. Beckett, "Airborne Infrared Target Tracking with the Nintendo Wii Remote Sensor," Texas A\&M University, 2012.

[6]. G. Buchanan, D. Wright, et al, "The Development of Rocketry Capability in New Zealand-World Record Rocket and First of Its Kind Rocketry Course," aerospace, vol. 2, pp. 91-117, 2015.

[7]. H. Bryson, G. Buchanan, et al, "Vertical Wind Tunnel for Prediction of Rocket Flight Dynamics," aerospace, vol. 3, no. 10, 2016.

[8]. V. Bharadwaj, "Colours: A Scientific Approach," in Composition of Colours, 2014, pp. 1-6. 